\title{
Morphological differentiation among migratory fish species from the Paraná River basin
}

\author{
Lucileine de Assumpção ${ }^{1,5}$, Maristela Cavicchioli Makrakis ${ }^{1}$, Sergio Makrakis ${ }^{1}$, Pitágoras Augusto Piana ${ }^{2}$, \\ Patrícia Sarai da Silva ${ }^{1}$, Ariane Furtado de Lima ${ }^{3}$ \& Domingo Rodriguez Fernandez ${ }^{4}$
}

\author{
${ }^{1}$ Grupo de Pesquisa em Tecnologia de Produção e Conservação de Recursos Pesqueiros e Hídricos - \\ GETECH, Universidade Estadual do Oeste do Paraná - UNIOESTE, Rua da Faculdade, 645, \\ CEP 85903-000, Toledo, PR, Brasil \\ ${ }^{2}$ Centro de Engenharia e Ciências Exatas, Universidade Estadual do Oeste do Paraná - UNIOESTE, \\ Rua da Faculdade, 645, CEP 85903-000, Toledo, PR, Brasil \\ ${ }^{3}$ Grupo de Pesquisa em Tecnologia de Produção e Conservação de Recursos Pesqueiros e Hídricos- \\ GETECH, Pós-graduação em Recursos Pesqueiros e Engenharia de Pesca, Universidade Estadual do \\ Oeste do Paraná - UNIOESTE, Rua da Faculdade, 645, CEP 85903-000, Toledo, PR, Brasil \\ ${ }^{4}$ Setor de Ictiologia, Itaipu Binacional, Av. Tancredo Neves, 6731, CEP 85866-900, \\ Foz do Iguaçu, PR, Brasil \\ ${ }^{5}$ Corresponding author: Lucileine de Assumpção, e-mail: lucileinea@hotmail.com
}

ASSUMPÇÃO, L., MAKRAKIS, M.C., MAKRAKIS, S., PIANA, P.A., SILVA, P.S., LIMA, A.F. \& FERNANDEZ, D.R. Morphological differentiation among migratory fish species from the Paraná River basin. Biota Neotrop. 12(4): http://www.biotaneotropica.org.br/v12n4/en/abstract?article+bn00512042012

\begin{abstract}
This study characterized the morphological differences among migratory fish species from the Paraná River Basin. A total of 177 adult fish of Leporinus elongatus, Leporinus macrocephalus, Prochilodus lineatus, Salminus brasiliensis, Pimelodus maculatus, Pinirampus pirinampu, Pseudoplatystoma corruscans, Pterodoras granulosus, and Rhaphiodon vulpinus were sampled in the Canal da Piracema, a fish passage system at Itaipu Dam, Paraná River. The migratory species were analyzed through 22 morphometric measurements and fineness ratio to identify morphological patterns related to swimming performance. Four species groups were indicated by the Cluster analysis: I) R. vulpinus; II) P. corruscans; III) L. macrocephalus, L. elongatus, P. lineatus, P. maculatus, and $S$. brasiliensis - measurements of head height and anal fin length formed this group; and IV) P. granulosus and $P$. pirinampu - measurements of maximum body width and caudal peduncle width contributed to form this group. The morphometric variables that most contributed to the distinction were head length and mouth width for groups I and II. The species R. vulpinus and P. granulosus differed from other species, showing fineness ratios of 9.4 and 3.7, respectively. Leporinus elongatus, L. macrocephalus, P. lineatus, P. maculatus, and S. brasiliensis showed significant differences from other species, with ratios ranging from 4.57 to 5.19 , indicating that these species may be better swimmers. Long-distance migratory species using the Piracema Canal to ascend upstream areas differed morphologically, morphological characteristics such as a narrow caudal peduncle and maximum body length, besides to the values of the fineness ratio, were essential to differentiate the migratory species.

Keywords: morphology, swimming performance, fineness ratio, migratory fish.
\end{abstract}

ASSUMPÇÃO, L., MAKRAKIS, M.C., MAKRAKIS, S., PIANA, P.A., SILVA, P.S., LIMA, A.F. \& FERNANDEZ, D.R. Diferenciação morfológica entre espécies de peixes migradores da bacia do Rio Paraná. Biota Neotrop. 12(4): http://www.biotaneotropica.org.br/v12n4/pt/abstract?article+bn00512042012

Resumo: Este estudo caracterizou as diferenças morfológicas entre espécies de peixes migradores da bacia do rio Paraná. Um total de 117 peixes adultos das espécies Leporinus elongatus, Leporinus macrocephalus, Prochilodus lineatus, Salminus brasiliensis, Pimelodus maculatus, Pinirampus pirinampu, Pseudoplatystoma corruscans, Pterodoras granulosus e Rhaphiodon vulpinus foram capturados no Canal da Piracema, um sistema de transposição para peixes na barragem de Itaipu, rio Paraná. As espécies migradoras foram analisadas através de 22 medidas morfométricas e razão fineza para identificar padrões morfológicos relacionados à capacidade natatória. Quatro grupos de espécies foram evidenciados pela Análise de Cluster: I) R. vulpinus; II) P. corruscans; III) L. macrocephalus, L. elongatus, P. lineatus, P. maculatus e $S$. brasiliensis, medidas de altura de cabeça e comprimento da nadadeira anal formaram este grupo; e IV) $P$. granulosus e P. pirinampu - medidas de largura máxima do corpo e largura do pedúnculo caudal contribuíram para a formação deste grupo. As variáveis morfométricas que mais contribuíram para distinção dos grupos I e II foram comprimento da cabeça e largura da boca. As espécies R. vulpinus e P. granulosus diferiram das demais, apresentando razão de fineza de $9,4 \mathrm{e}$ 3,7, respectivamente. Leporinus elongatus, L. macrocephalus, P. lineatus, P. maculatus, S. brasiliensis diferiram significativamente das demais espécies com valores de razão fineza que variaram entre 4,57 a 5,19, indicando que estas espécies podem apresentar melhor desempenho natatório. As espécies migradoras de longa distância que utilizam o Canal da Piracema para ascender áreas a montante diferiram morfologicamente, características morfológicas como pedúnculo caudal estreito e largura máxima do corpo, bem como os valores de razão de fineza foram determinantes na diferenciação das espécies aqui analisadas.

Palavras-chave: morfologia, capacidade natatória, razão fineza, peixe migrador. 


\section{Introduction}

Morphological and morphometric variations in the fish body structure can lead to functional differences in the performance and locomotion (Breda et al. 2005, Motta \& Wilga 1995, Wainwright et al. 2002). The swimming performance depends on a species' morphological characteristics (Lighthill 1969) so many fish morphological characteristics are important to define it, especially those related to production of thrust and drag force as body shape, height of caudal peduncle, length of caudal fin (Webb \& Weihs 1986) and fineness ratio (Bainbridge 1960, Landweber 1961, Blake 1983). These characteristics can describe the influence of body shape on the drag in water movement (Ohlberger et al. 2006).

In the conception and implementation of barriers to movement of water flow, as culverts, canals, dikes and dams (Warren \& Pardew 1998), the fish swimming performance is an important factor that should be taken into consideration (Beach 1984, Santos et al. 2008), especially for those species that are rheophilic, showing upward migration for reproduction (Agostinho et al. 1992, 2007). However, the swimming performance and morphological characteristics of the Neotropical fish species that may use the fish passages have not been considered in the design criteria.

Studies on morphology of Neotropical freshwater fish are restricted to the comparison between morphology and diet (Piorski et al. 2005, Teixeira \& Bennemann 2007), morphological variations under different environmental conditions (Monteiro \& Neves 2003), and ecomorphology of fish from streams (Casatti \& Castro 2006, Ferreira 2007). However, studies on the morphology associated with swimming performance for the Neotropical fish species are non-existent, with only information available for two migratory species, Leporinus reinhardti and Pimelodus maculatus, on swimming speeds and determination of swimming performance in the studies conducted by Santos et al. $(2007,2008)$.

This study characterized the morphological differences among nine long-distance migratory fish species from Paraná River basin, based on morphometric measurements, in order to identify morphological patterns related to the swimming performance, important information to subside the design criteria of the fish passages in the Neotropical region.

\section{Materials and Methods}

\section{Samples and collection of morphometric data}

Fish sampling was carried out from April/2004 to May/2005 (April, May, and August to December/2004, and January to May/2005) in the Piracema Canal, a fish-pass system located at the Itaipu Dam, Paraná River, Brazil-Paraguay (Figure 1).

The Piracema Canal is a complex $10-\mathrm{km}$ fish pass system that climbs $120 \mathrm{~m}$ to connect the Paraná River to the Itaipu Reservoir along the Brazil-Paraguay border (Makrakis et al. 2011). The canal includes a large section of a natural streambed as well as several fish ladders, artificial lakes and semi-natural channels, and the mean water velocity range from 0.9 to $3.0 \mathrm{~m} / \mathrm{s}$ (for details see Makrakis et al. 2007).

Fish collections were made in different locations along the Piracema Canal, including in the Paraná River (downstream of the dam) and the Itaipu Reservoir, using several fishing gears: gill nets, casting net, trawl net, and fishing rod.

To analyze the most appropriate morphological patterns for the species' movement related to swimming capacity, morphometric measurements were taken in nine long-distance migratory fish species (Agostinho et al. 2003, Suzuki et al. 2004, Makrakis et al. 2007), totaling 177 individuals (Table 1).
Only adults were analyzed, because they did not show changes in proportion during their growth (allometry) (Gatz Junior 1979a, b). The measurements were taken according to Gatz Junior (1979a), Watson \& Balon (1984), totaling 22 morphometrics measurements (Figure 2).

The measurements up to $150 \mathrm{~mm}$ were made with a digital caliper of $0.5 \mathrm{~mm}$ precision; and above $150 \mathrm{~mm}$, with a metal ruler of $1.0 \mathrm{~mm}$ precision. To make the measurements, the live fish were previously anesthetized with clove oil.

\section{Data analysis}

To evaluate the morphological similarities among the species, the residues of linear regressions between the standard length (independent variable) and the morphometric measurements (dependent variables) were used to produce a similarity/dissimilarity matrix (Cone 1989), using Euclidean Distance. These circumstances were classified through grouping analysis (Cluster analysis) applying the Single Link Method, where individual pairs are united, each time, closer to each other (Wilkinson 1987). Non-metric Multidimensional Scaling (MDS), followed by Pearson and Spearman correlations between the retained axes, and the variables that originated them, were applied to complement the patterns of species relationships found, utilizing the clustering procedure, and to illustrate the relationships in a two-dimensional space. The procedure for MDS was calculated with 25 restarts to arrive at a minimum stress value $(0.01)$, in accordance with the procedures suggested by Field et al. (1982) and Clarke (1993). The percentage similarity of routine analysis for the delineation of each group was determined by the SIMPER procedure (Clarke 1993). This procedure indicates the average contribution of each morphometric measurement to the similarity/dissimilarity. The PRIMER v.6 software (Clarke \& Gorley 2006) was used in the multivariate analysis.

The fineness ratio (Landweber 1961, Webb 1975, Blake 1983) was calculated for each individual to assess the influence of body shape on swimming performance as follows (Equation 1):

$$
\text { Fineness ratio }=\frac{\mathrm{SL}}{\sqrt{\mathrm{MBH}^{*} \mathrm{MBW}}}
$$

SL: standard length; MBH: maximum body height; MBW: maximum body width.

Table 1. Number of fish analyzed of the long-distance migratory species. Tabela 1. Número de peixes analisados das espécies migradoras de longa distância.

\begin{tabular}{lc}
\hline \multicolumn{1}{c}{ Family/species } & Number of individuals \\
\hline Anostomidae & 15 \\
Leporinus elongatus & 4 \\
Leporinus macrocephalus & \\
Prochilodontidae & 39 \\
Prochilodus lineatus & \\
Characidae & 14 \\
Salminus brasiliensis & \\
Pimelodidae & 39 \\
Pimelodus maculatus & 11 \\
Pinirampus pirinampu & 4 \\
Pseudoplatystoma corruscans & \\
Doradidae & 5 \\
Pterodoras granulosus & \\
Cynodontidae & 46 \\
Rhaphiodon vulpinus & 117 \\
Total & \\
\hline
\end{tabular}




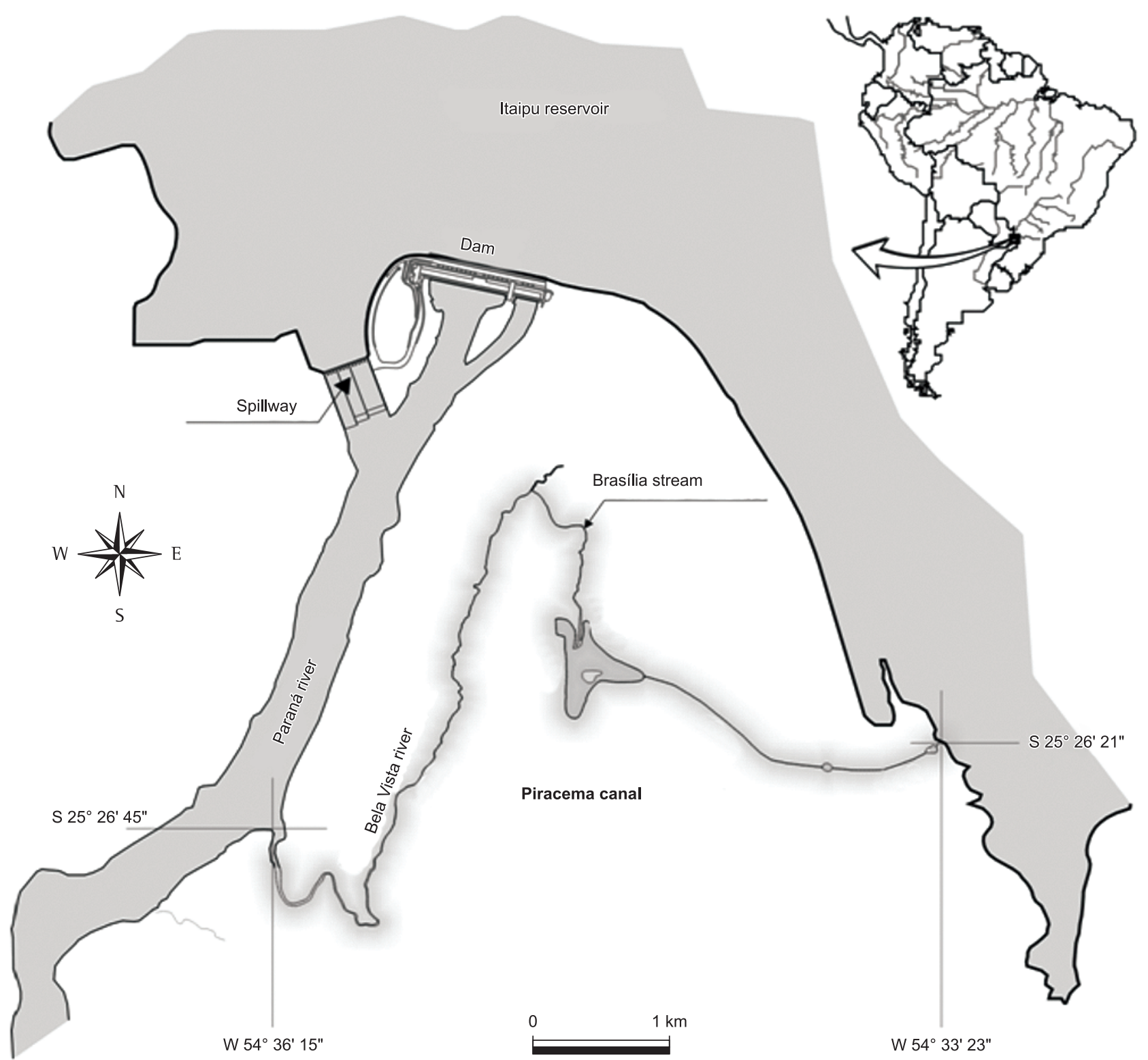

Figure 1. Piracema Canal, connecting the Paraná River and Itaipu Reservoir.

Figura 1. Canal da Piracema, que liga o rio Paraná ao Reservatório de Itaipu.

To assess whether the species showed a different fineness ratio, the variance analysis (ANOVA-One way) was applied, followed by the a posteriori Tukey test, both at the 5\% level of significance.

\section{Results}

From the dendrogram of the species' morphological relationships and the MDS ordination technique (Figure 3), we found that the degree of morphological similarity among the species resulted in four clusters (groups I, II, III, and IV). These groups defined in the dendrogram (level 5.1) are evident in the ordination analysis, non-metric MDS, with a stress of 0.01 , indicating that the graphical distances among the species were close to the original similarities. The correlations between the retained axes and the morphometric measurements showed that dimension 1 (MDS 1) was positively related to eye height (EH), anal fin length (AFL), and fineness ratio.
In relation to negative values, maximum body width (MBW), caudal peduncle length $(\mathrm{CPdL})$, caudal peduncle width $(\mathrm{CPdW})$, and head width (HW) were prominent. Dimension 2 (MDS 2) showed a positive relationship only to maximum body height (MBH), caudal peduncle height $(\mathrm{CPdH})$, and head height $(\mathrm{HH})$, and negative to mouth height $(\mathrm{MoH})$ (Figure 3, Table 2).

The analysis of similarity percentage (SIMPER procedure) (Table 3 ) and the dendrogram showed that group I was formed only by $R$. vulpinus, while group II included only $P$. corruscans. Group III was formed by two subgroups, one by $L$. macrocephalus, and the other by L. elongatus, P. lineatus, P. maculatus, and S. brasiliensis. Measurements of head height (HH) and anal fin length (AFL) were essential to form the group. Group IV, which showed a similarity of 11.83, was characterized by P. granulosus and P. pirinampu, and the measurements that contributed most to form this group were maximum body width (MBW) and caudal peduncle width (CPdW). 


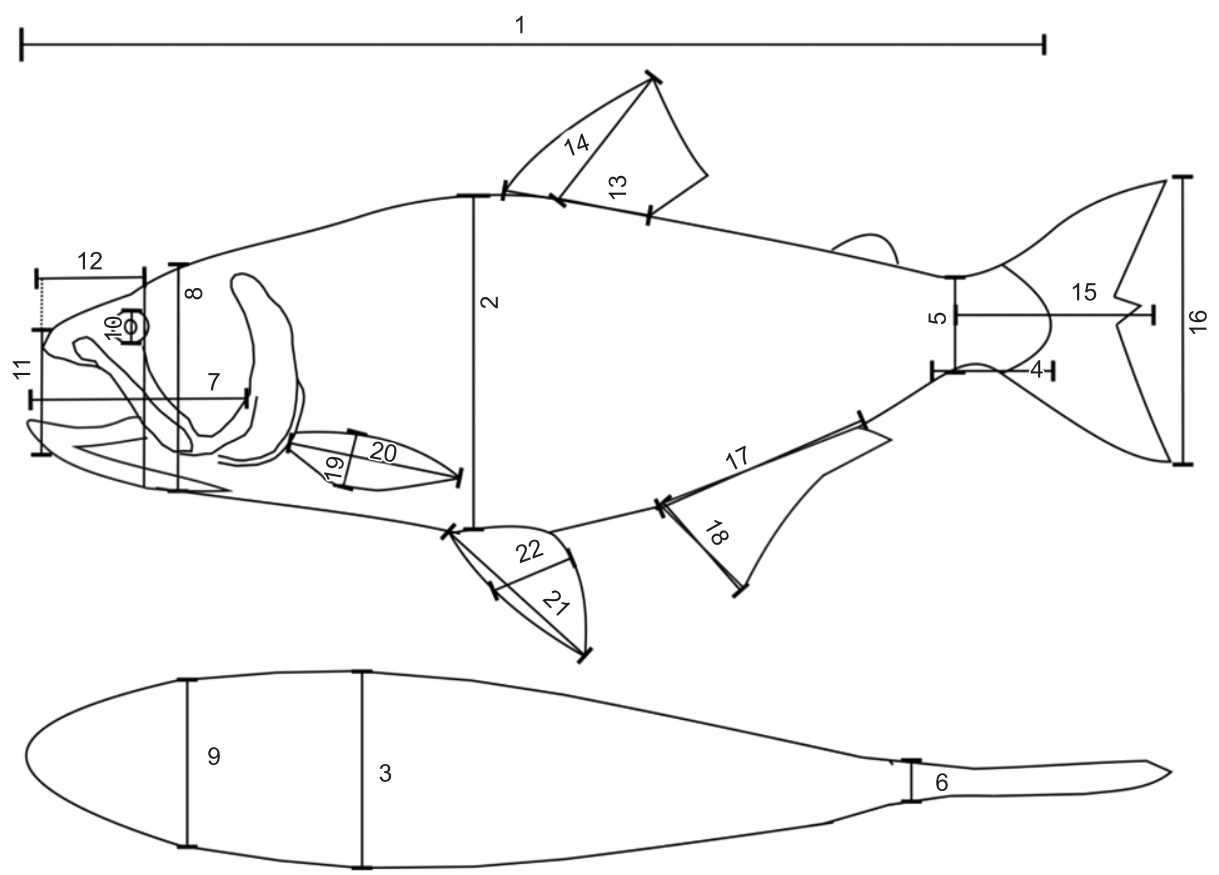

Figure 2. Morphological measurements: 1) standard body length (SBL), 2) maximum body height (MBH), 3) maximum body width (MBW), 4) caudal peduncle length (CPdL), 5) caudal peduncle height (CPdH), 6) caudal peduncle width (CPdW), 7) head length (HL), 8) head height (HH), 9) head width (HW), 10) eye height (EH), 11) mouth height (MoH), 12) mouth width (MoW), 13) dorsal fin length (DFL), 14) dorsal fin height (DFH), 15) caudal fin length ( CFL), 16) caudal fin height $(\mathrm{CFH}), 17)$ anal fin length $(\mathrm{AFH}), 18)$ anal fin height $(\mathrm{AFH}), 19)$ pectoral fin length (PtFL), 20) pectoral fin height (PtFH), 21) pelvic fin length (PFL), and 22) pelvic fin height (PFH).

Figura 2. Representação das medidas morfológicas: 1) comprimento padrão do corpo (CP), 2) altura máxima do corpo (ALMCp), 3) largura máxima do corpo (LMCp), 4) comprimento do pedúnculo caudal (CPd), 5) altura do pedúnculo caudal (ALPd), 6) largura do pedúnculo caudal (LPd), 7) comprimento da cabeça (CCa), 8) altura da cabeça (ALCa), 9) largura da cabeça (LCa), 10) altura do olho (ALO), 11) altura da boca (ALBo), 12) largura da boca (LBo), 13) comprimento da nadadeira dorsal (CND), 14) altura da nadadeira dorsal (ALND), 15) comprimento da nadadeira caudal (CNC), 16) altura da nadadeira caudal (ALNC), 17) comprimento da nadadeira anal (CNA), 18) altura da nadadeira anal (ALNA), 19) comprimento da nadadeira peitoral (CNPt), 20) altura da nadadeira peitoral (ALNPt), 21) comprimento da nadadeira pélvica (CNPv) e 22) altura da nadadeira pélvica (ALNPv).

The dissimilarity ranged from 40.28 to 107.23 comparing group to group, and the morphometric variables that most contributed to the distinction were: i) head length (HL) and mouth width (MoW) for groups I and II; ii) head height (HH), dorsal fin length (DFL), and pectoral fin length (PtFL) for groups I and III; iii) maximum body height (MBH), head length (HL), and mouth width (MoW) for groups II and III; iv) pectoral fin height (PtFH), pectoral fin length (PtFL), and caudal peduncle width (CPdW) for groups III and IV; v) pectoral fin height $(\mathrm{PtFH})$, head length (HL), and pectoral fin length (PtFL) for groups II and IV; vi) maximum body width (MBW) and caudal peduncle width (CPdW) for groups I and IV (Table 3).

The mean values of fineness ratio differed significantly among the nine species (ANOVA: $F=510.3 ; p=0.001$ ) (Figure 4). The Tukey test showed that $R$. vulpinus and $P$. granulosus differed from other species, displaying the highest (9.41) and lowest (3.77) fineness ratios, respectively. Leporinus elongatus, L. macrocephalus, P. lineatus, P. maculatus, and S. brasiliensis differed from other species (Figure 4), with intermediate values ranged from 4.57 to 5.19. Similar fineness ratios were verified to $P$. corruscans and $P$. pirinampu (between 6.04 and 6.11, respectively).

\section{Discussion}

The swimming performance of fish is not only related to the ecology of organisms that affects prey capture (Rincón et al. 2007) and reproductive success (Videler 1993, Fisher \& Bellwood 2003), but also the morphological characteristics of the body, demonstrating that it has a significant effect on aquatic vertebrates (Webb 1984, Blake 2004) and a focus of research in theoretical and applied studies (Hawkins \& Quinn 1996, Ojanguren \& Brana 2003, Rincón et al. 2007). Morphological characteristics can be used to predict functional differences in the movement and swimming performance, which can result in the incorporation of parameters essential to swimming into ecological studies (Fisher \& Hogan 2007).

The morphological patterns identified for the nine long-distance migratory fish species analyzed, which separated them into four distinct morphological groups, may indicate the existence of differences in the swimming capacity and modes of locomotion. Group I was formed exclusively by $R$. vulpinus, a piscivorous species living in the upper layers of the water column, migrator (Ferreira \& Caramaschi 2005, Agostinho et al. 2003), and its morphology is adapted to capture prey on the surface or medium depths (Almeida et al. 1997). Therefore, R. vulpinus differentiated from other migratory species studied for its body shape, long and laterally compressed body as evidenced by fineness ratio (higher values). In addition, it has a superior-placed mouth, appropriate for predation at the water surface, lateral eyes, short caudal peduncle and large pectoral fins that facilitate fast movements to catch its prey (Freire \& Agostinho 2001). On the other hand, the group II, including only P. corruscans, showed morphological differences from $R$. vulpinus, with larger mouth opening and higher length of the head. 

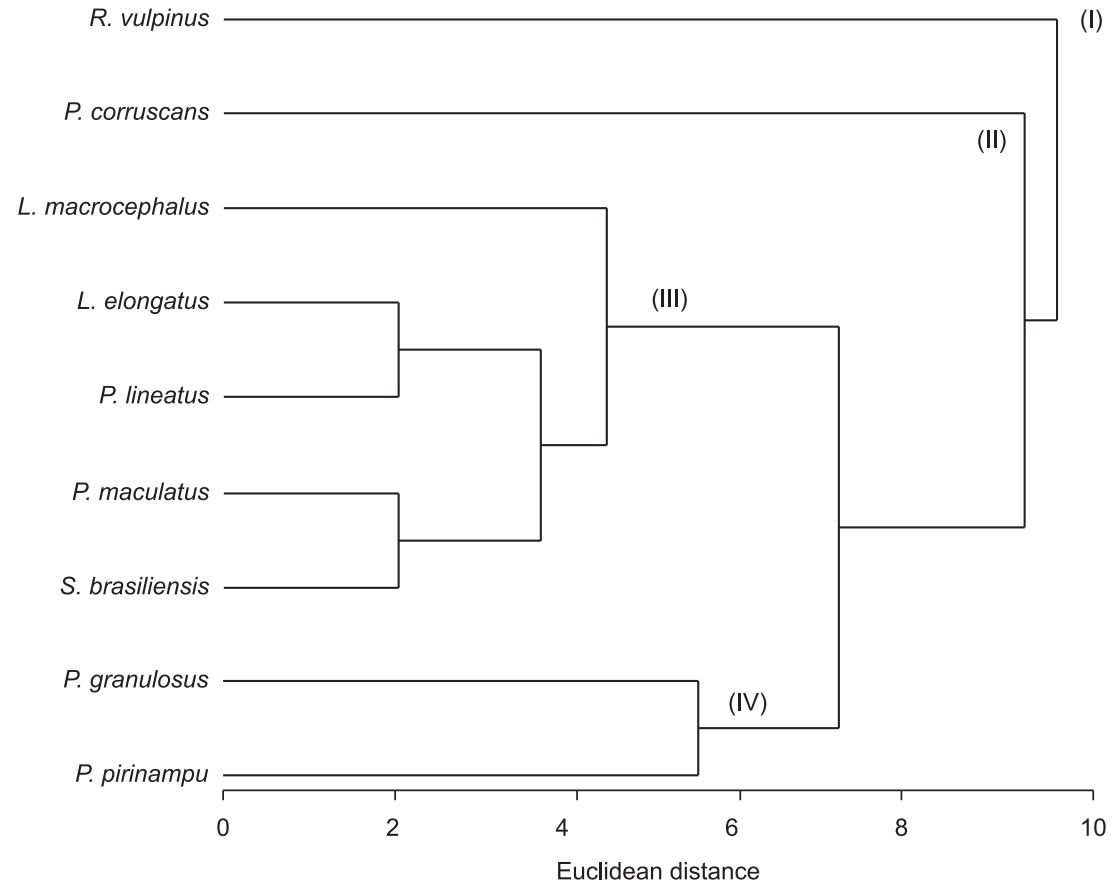

(b)

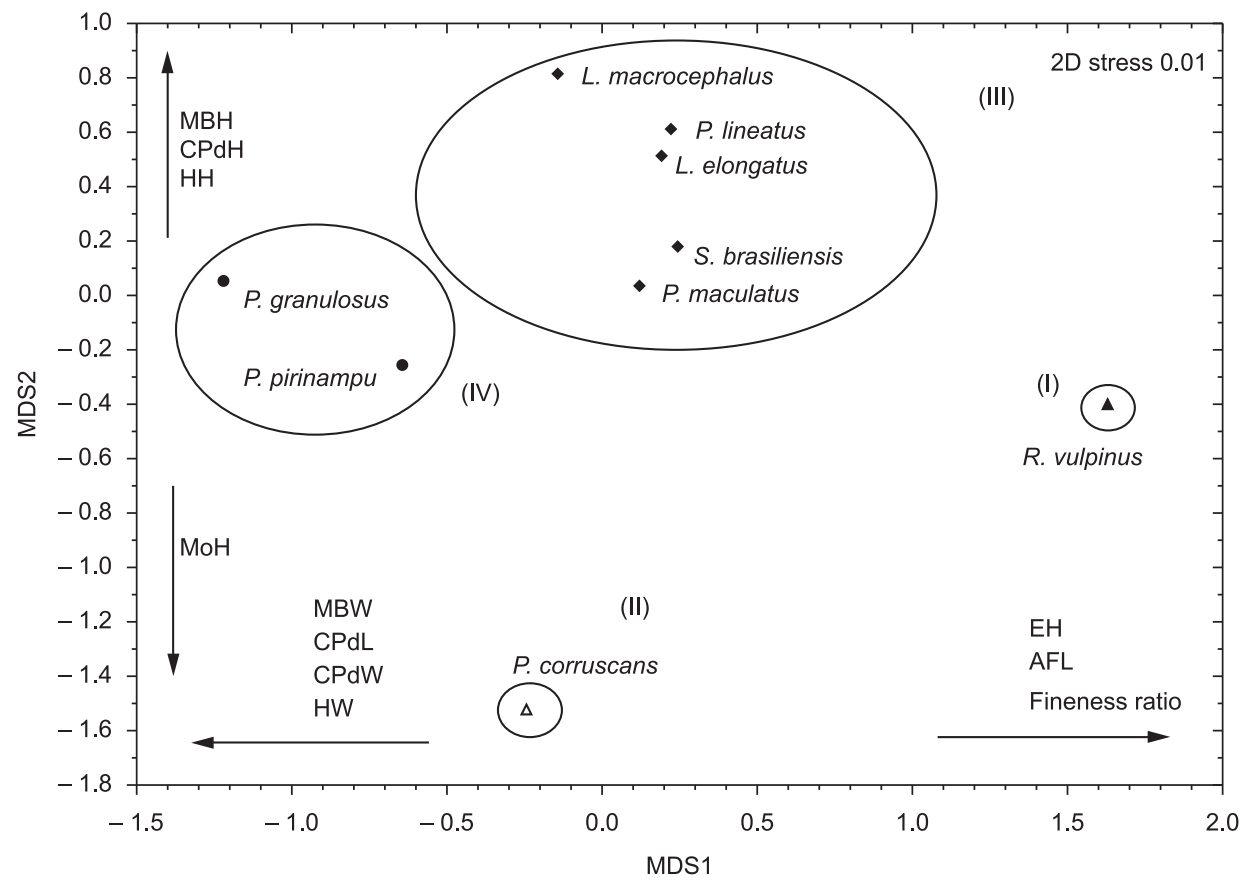

Figure 3. Dendrogram and ordering by the MDS method of morphometric measurements of nine long-distance migratory fish species of the Paraná River. Fish species groups delineated at the 5.1 similarity level on the dendrogram are circled on the ordering graph.

Figura 3. Dendograma e ordenação pelo método MDS das medidas morfométricas de nove espécies de peixes migradores de longa distância do rio Paraná. Grupos de espécies de peixes delineados no nível de 5,1\% de similaridade no dendograma estão circundados no gráfico de ordenação.

Morphological characteristics may determine the body shape more efficient (streamlined bodies) to minimize drag and maximize thrust allowing swimming at high speeds for longer time. The shape streamlining considered the most ideal for a more efficient swimming is usually described by the fineness ratio (Scarnecchia 1988), with this attribute can evaluate the swimming performance of fish (Landweber 1961, Blake 1983, Videler \& Wardle 1991, Videler 1993, Langerhans \& Reznick 2010). The group III was composed by the species L. macrocephalus, L. elongatus, P. lineatus, P. maculatus and $S$. brasiliensis, showing lower head height and length of the anal fin. These species exhibit a hydrodynamic body characterized by elongated and fusiform body shape. The fusiform body shape is 
Table 2. Pearson and Spearman correlations among the MDS axes.

Tabela 2. Correlação de Pearson e Spearman entre os eixos da MDS.

\begin{tabular}{|c|c|c|c|c|}
\hline \multirow{2}{*}{ Variables } & \multicolumn{2}{|c|}{ Pearson (r) } & \multicolumn{2}{|c|}{ Spearman $(\rho)$} \\
\hline & MDS 1 & MDS 2 & MDS 1 & MDS 2 \\
\hline Fineness ratio & 0.76 & -0.46 & 0.32 & -0.73 \\
\hline Eye height (EH) & 0.69 & 0.67 & 0.83 & 0.40 \\
\hline Anal fin length (AFL) & 0.67 & 0.02 & 0.52 & -0.15 \\
\hline Mouth height $(\mathrm{MoH})$ & 0.09 & -0.85 & -0.20 & -0.83 \\
\hline Caudal peduncle height $(\mathrm{CPdH})$ & 0.04 & 0.90 & 0.25 & 0.93 \\
\hline Pectoral fin length (PtFL) & -0.01 & -0.21 & -0.08 & -0.45 \\
\hline Head height $(\mathrm{HH})$ & -0.07 & 0.83 & 0.30 & 0.93 \\
\hline Maximum body height (MBH) & -0.09 & 0.96 & 0.17 & 0.98 \\
\hline Head length (HL) & -0.29 & -0.67 & -0.22 & -0.08 \\
\hline Caudal fin height (CFH) & -0.45 & 0.75 & -0.17 & 0.75 \\
\hline Dorsal fin length (DFL) & -0.46 & 0.75 & 0.07 & 0.90 \\
\hline Mouth width (MoW) & -0.56 & -0.78 & -0.68 & -0.53 \\
\hline Caudal fin length (CFL) & -0.59 & 0.30 & -0.30 & 0.22 \\
\hline Pectoral fin height (PtFH) & -0.73 & 0.18 & -0.63 & 0.28 \\
\hline Pelvic fin length (PFL) & -0.75 & 0.23 & -0.48 & 0.30 \\
\hline Anal fin height (AFH) & -0.81 & 0.30 & -0.43 & 0.27 \\
\hline Maximum body width (MBW) & -0.87 & -0.14 & -0.73 & 0.17 \\
\hline Caudal peduncle length (CPdL) & -0.87 & 0.20 & -0.57 & 0.40 \\
\hline Dorsal fin height (DFH) & -0.87 & 0.17 & -0.62 & 0.25 \\
\hline Pelvic fin height (PFL) & -0.88 & -0.17 & -0.87 & -0.18 \\
\hline Caudal peduncle width (CPdW) & -0.90 & 0.12 & -0.78 & 0.18 \\
\hline Head width (HW) & -0.93 & -0.15 & -0.95 & -0.07 \\
\hline
\end{tabular}

Values in bold indicate $\mathrm{p}<0.05$. Valores em negrito indica $\mathrm{p}<0,05$.

Table 3. Contribution of morphometric measurements to the similarity (S) and dissimilarity (D) of the groups (I-IV) of long-distance migratory fish species. Tabela 3. Contribuição das medidas morfométricas para a similaridade (S) e dissimilaridade (D) dos grupos (I-IV) de espécies de peixes migradores de longa distância.

\begin{tabular}{|c|c|c|c|c|c|c|c|c|}
\hline \multirow{2}{*}{ Mesures } & III & IV & III-I & III-II & III-IV & II-I & II-IV & IV-I \\
\hline & $S=5.70$ & $\mathrm{~S}=11.83$ & $D=59.98$ & $\mathrm{D}=71.48$ & $D=40.28$ & $D=107.23$ & $\mathrm{D}=\mathbf{5 9 . 4 8}$ & $D=95.79$ \\
\hline $\mathrm{MoH}$ & 4.53 & 8.22 & 3.99 & 3.83 & 4.54 & - & - & - \\
\hline $\mathrm{HH}$ & 21.81 & 7.35 & 7.72 & 9.92 & 9.26 & - & - & - \\
\hline $\mathrm{MBH}$ & 4.25 & 3.04 & 5.57 & 11.85 & 3.43 & - & 6.20 & - \\
\hline $\mathrm{AFH}$ & 2.52 & 2.59 & 4.39 & - & - & - & 2.46 & 5.34 \\
\hline $\mathrm{CFH}$ & 4.38 & 0.01 & 4.83 & 3.47 & - & - & 3.18 & - \\
\hline DFH & 1.38 & 0.47 & 4.72 & - & 3.19 & - & 3.62 & 7.96 \\
\hline $\mathrm{PtFH}$ & 0.80 & 1.74 & - & - & 10.36 & - & 13.63 & 6.57 \\
\hline PFL & 1.57 & 0.16 & 5.77 & - & - & 7.33 & - & 5.76 \\
\hline $\mathrm{EH}$ & 4.14 & 0.00 & - & 10.07 & 8.34 & 9.47 & - & 5.62 \\
\hline $\mathrm{CPdH}$ & 4.69 & 1.86 & 6.23 & 9.18 & 5.71 & - & 2.27 & - \\
\hline HL & 3.35 & 1.07 & - & 20.36 & - & 24.84 & 27.99 & - \\
\hline AFL & 12.32 & 0.18 & 6.3 & - & - & 7.28 & - & 4.64 \\
\hline CFL & 6.51 & 3.97 & - & - & - & - & - & 2.63 \\
\hline DFL & 3.32 & 0.01 & 7.44 & 2.46 & - & - & - & - \\
\hline PtFL & 6.55 & 0.62 & 7.56 & - & 11.27 & 6.18 & 11.13 & - \\
\hline PFL & 2.71 & 2.16 & 6.01 & - & - & 2.49 & & 5.50 \\
\hline CPdL & 0.08 & 1.46 & 5.01 & - & 3.72 & - & 5.12 & 8.99 \\
\hline MoW & 7.59 & 0.59 & - & 16.53 & 7.27 & 14.99 & 5.45 & 5.17 \\
\hline HW & 4.95 & 7.95 & 5.72 & 2.56 & 5.44 & 8.70 & - & 9.97 \\
\hline MBW & 0.41 & 29.61 & 5.1 & - & 7.85 & 8.51 & 2.96 & 10.75 \\
\hline CPdW & 2.15 & 26.94 & 4.33 & - & 10.72 & 2.61 & 6.60 & 12.36 \\
\hline
\end{tabular}

For measure codes see Table 2. Para os códigos das medidas ver Tabela 2. 


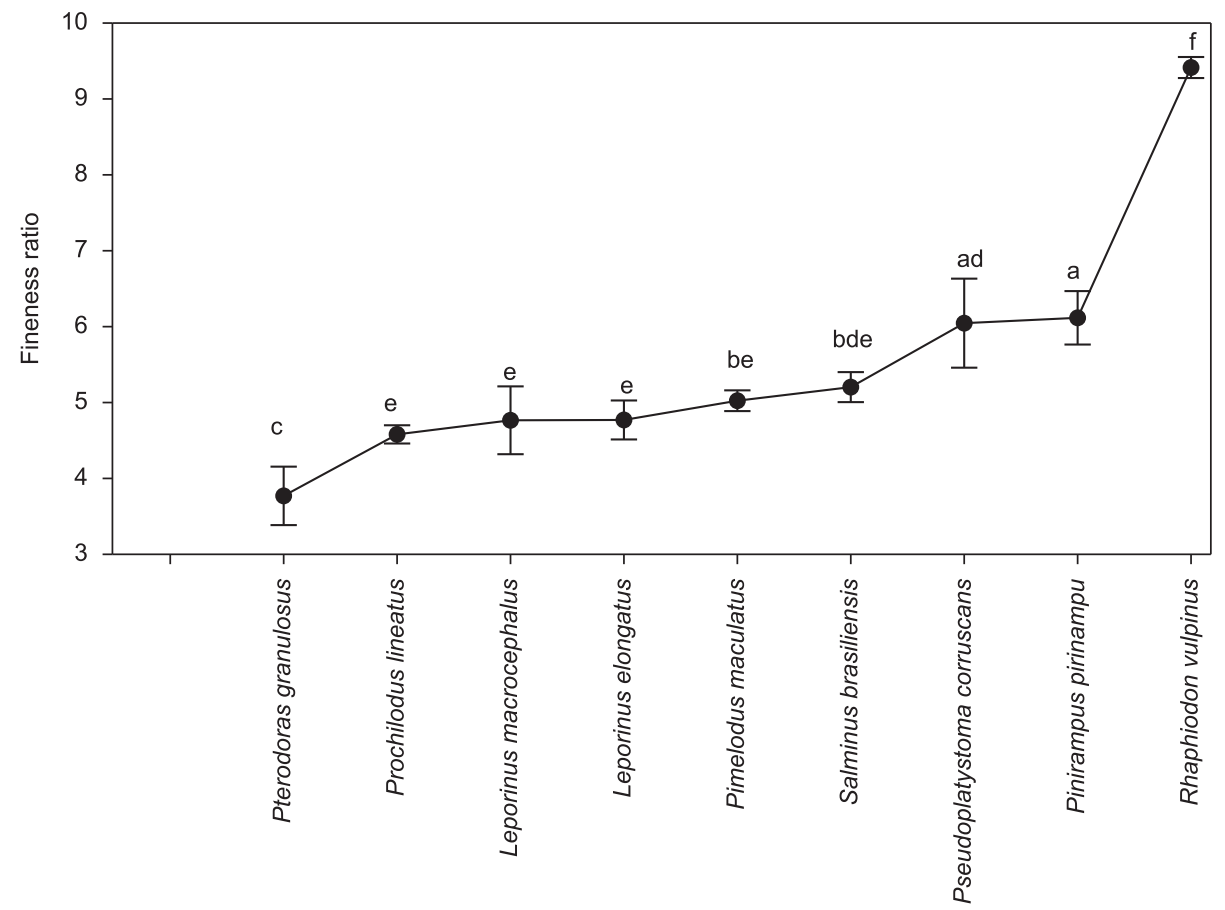

Figure 4. Mean $\pm 95 \%$ standard deviation for the fineness ratios of the nine fish species evaluated. Different letters indicate significant differences in the a posteriori Tukey test.

Figura 4. Média $\pm 95 \%$ de intervalo de confiança para a razão fineza das diversas espécies avaliadas. Letras distintas indicam diferenças significativas pelo teste de Tukey a posteriori.

characterized by the maximum height located at the anterior region of the body; the slender caudal peduncle and high caudal fin soften the opposite forces to the movement (Lagler et al. 1977, Breda et al. 2005). Thus, species from group III may have a higher swimming performance in relation to other species studied, as observed by the values of fineness ratio. Studies conducted in the Piracema Canal by Makrakis et al. (2007) demonstrated that the species Leporinus elongatus, L. obtusidens, P. lineatus and Salminus brasiliensis, all species considered good swimmers, pass easier through the Piracema Canal. This feature may also be attributed to the morphological characteristics of these species, because they have been the most hydrodynamic body providing greater performance swimming.

Differences in the shape and length of caudal peduncle are known as important attributes related to swimming ability (Bandyopadhyay et al. 1997), and the propulsive force is related to the width of the caudal peduncle (Gosline 1971). The species $P$. granulosus and $P$. pirinampu, group IV, have higher maximum width of the body and narrower caudal peduncle causing decrease of the waves provoked by the movement of the anterior region of the body associated with a high caudal fin that promote greater thrust (Aleev 1969). Moreover, the swimming performance is related to the development of muscle mass, fineness ratio, and other characteristics associated to morphology that were not addressed in this study as muscle and propulsive ratios (Nanami 2007).

The fineness ratio, a dimensional measure of body fineness, can also provide information about the hydrodynamic shape of the fish body (Blake 2004, Ohlberger et al. 2006, Langerhans \& Reznick 2010). The species $R$. vulpinus and P. granulosus differ from other species presenting extreme values of fineness ratio. This ratio decreased with increasing fish muscle mass, indicating that $P$. granulosus with ventrally flattened body has higher muscle mass resulting in lower value of fineness ratio. The species has great width caudal peduncle and large pectoral and caudal fins, featuring P. granulosus as a great migrator (Freire \& Agostinho 2001). Morphologic and behavioral characteristic of Pterodoras granulosus such as depressed ventrally body and staying in areas near background which exhibits high stability, may allow the species take advantage in environments with high speed current (Alexander 1967).

The species $P$. corruscans and $P$. pirinampu inhabiting the lower strata of the water column characterizing bottom species showed similar average fineness ratio (6.0-6.1). Fineness ratios between 2 to 6 result in a drag reduction produced by the animal, and species with ratio of 4.5 have excellent swimming capacity (Von Mises 1945, Blake 1983). The similar fineness ratios found for L. elongatus, L. macrocephalus, P. lineatus, P. maculatus, and S. brasiliensis (4.57 to 5.19) indicate that these species are all relatively good swimmers. Studies on Cyprinus carpio and Rutilus rutilus have shown fineness ratios below $4.5 ; R$. rutilus showed higher values, characterizing it as a species with an adequate body form for swimming performance (Ohlberger et al. 2006). On the other hand, for Mugil cephalus cephalus, Webb (1975) showed that a fineness ratio of 4.5 reduces drag, thus demonstrating that the species may be close to its best swimming performance.

Long-distance migratory species using the Piracema Canal to ascend upstream areas differed morphologically and some morphological characteristics are considered important to relate to the swimming performance: narrow caudal peduncle, maximum width of the body, and fineness ratio were determinant for the differentiation of the four groups of long-distance migratory species. However, beyond these characteristics, studies on swimming performance as swimming speed of the Neotropical migratory fish species can be used to assess the fish passages, linking the environment with the morphological characteristics of species to predict the efficiency in ascending fish passages. 


\section{Acknowledgements}

We are thankful to Itaipu Binacional for financial and logistic support to carry out this study. We also are grateful to the Núcleo de Pesquisas em Limnologia, Ictiologia e Aquicultura (Nupélia) for logistic support, and especially for help in fieldwork.

\section{References}

AGOSTINHO, A.A., JÚLIO JUNIOR, H.F. \& BORGHETTI, J.R. 1992. Considerações sobre os impactos dos represamentos na ictiofauna e medidas para sua atenuação. Um estudo de caso: Reservatório de Itaipu. Rev. Unimar. 14:89-107.

AGOSTINHO, A.A., GOMES, L.C., SUZUKI, H.I. \& JÚLIO JUNIOR, H.F. 2003. Migratory fishes of the Upper Paraná River Basin Brazil. p. 19-89. In Migratory Fishes of South America: Biology, Fisheries and Conservation Status (J. Carolsfeld, B. Harvey, C. Ross \& A. Baer, eds.). World Bank, Vitoria.

AGOSTINHO, C.S., PEREIRA, C.R., OLIVEIRA, R.J., FREITAS, I.S. \& MARQUES, E.E. 2007. Movements through a fish ladder: temporal patterns and motivations to move upstream. Neotrop. Ichthyol. 5(2):161167. http://dx.doi.org/10.1590/S1679-62252007000200010

ALEEV, Y.G. 1969. Function and gross morphology in fish. Program for Scientific Translations, Jerusalem.

ALEXANDER, R.M.N. 1967. Functional design in fishes. Hutchinson University Library, London.

ALMEIDA, V.L.L., HAHN, N.S. \& VAZZOLER, A.E.A.M. 1997. Feeding patterns in five predatory fishes of the high Paraná river floodplain (PR, Brazil). Ecol. Freshw. Fish. 6:123-133. http://dx.doi. org/10.1111/j.1600-0633.1997.tb00154.x

BAINBRIDGE, R. 1960. Speed and stamina in three fish. J. Exp. Biol. 37(1):129-153.

BANDYOPADHYAY, P.R., CASTANO, J.M., RICE, J.Q., PHILLIPS, R.B., NEDDERMAN, W.H. \& MACY, W.K. 1997. Low-speed maneuvering and hydrodynamics of fish and small underwater vehicles. J. Fluid. Eng. 119(11):136-144. http://dx.doi.org/10.1115/1.2819099

BEACH, M.H. 1984. Fish pass design - Criteria for the design and approval of fish passes and others structures to facilities the passage of migratory fishes in Rivers. Ministry of Agriculture, Fisheries and Food, 46p. Fisheries Research Technical Report, n.78.

BLAKE, R.W. 1983. Functional design and burst-and-coast swimming in fishes. Can. J. Zool. 61:2491-2494. http://dx.doi.org/10.1139/z83-330

BLAKE, R.W. 2004. Fish functional design and swimming performance. J. Fish. Biol. 65:1193-1222. http://dx.doi.org/10.1111/j.00221112.2004.00568. $\mathrm{x}$

BREDA, L., OLIVEIRA, E.F. \& GOULART, E. 2005. Ecomorfologia de locomoção de peixes com enfoque para espécies neotropicais. Acta Sci. Biol. Sci. 27(4):371-381. http://dx.doi.org/10.4025/actascibiolsci. v27i4.1271

CASATTI, L. \& CASTRO, R.M.C. 2006. Testing the ecomorphological hypothesis in a headwater riffles fish assemblage of the rio São Francisco, southeastern Brazil. Neotrop. Ichthyol. 4(2):203-214. http://dx.doi. org/10.1590/S1679-62252006000200006

CLARKE, K.R. \& GORLEY, R.N. 2006. Primer v.6: User Manual Tutorial. PRIMEr-E, Plymouth.

CLARKE, K.R. 1993. Non-parametric multivariate analyses of changes in community structure. Australian. J. Ecol. 18(1):117-143. http://dx.doi. org/10.1111/j.1442-9993.1993.tb00438.x

CONE, R.S. 1989. The need to reconsider the use of condition indices in fisheries science. Trans. Am. Fish. Soc. 118(5):510-514. http://dx.doi. org/10.1577/1548-8659(1989)118<0511:TNTRTU >2.3.CO;2

FERREIRA, M.F.N. \& CARAMASCHI, E.P. 2005. Aspectos da Estratégia Reprodutiva de Machos de Teleósteos na Área de Influência da Usina Hidrelétrica Serra da Mesa, Alto Rio Tocantins, GO. In Ecologia de Reservatórios: impactos potenciais, ações de manejo e sistemas em cascata (M.G. Nogueira, H. Raoul \& A. Jorcin). RIMA, São Carlos, 472p.
FERREIRA, K.M. 2007. Biology and ecomorphology of stream fishes from the river Mogi-Guaçu basin, Spoutheastern Brazil. Neotrop. Ichthyol. 5(3):311-326.

FIELD, J.G., CLARKE, K.R. \& WARWICK, R.M. 1982. A practical strategy for analyzing multispecies distribution patterns. Mar. Ecol. Prog. Ser. 8:37-52. http://dx.doi.org/10.3354/meps008037

FISHER, R. \& BELLWOOD, D.R. 2003. Undisturbed swimming behaviour and nocturnal activity of coral reef fish larvae. Mar. Ecol. Prog. Ser. 263:177-188. http://dx.doi.org/10.3354/meps263177

FISHER, R. \& HOGAN, J.D. 2007. Morphological predictors of swimming speed: a case study of pre-settlement juvenile coral reef fishes. J. Exp. Biol. 210(14):2436-2443. PMid:17601947. http://dx.doi.org/10.1242/ jeb.004275

FREIRE, A.G. \& AGOSTINHO, A.A. 2001. Ecomorfologia de oito espécies dominantes da ictiofauna do reservatório de Itaipu (Paraná/Brasil). Acta Limnol. Brasil. 13(1):1-9.

GATZ JUNIOR, A.J. 1979a. Ecological morphology of freshwater stream fishes. Tulanne Stud. Zool. Bot. 21(2):91-124.

GATZ JUNIOR, A.J. 1979b. Community organization in fishes as indicated by morphological features. Ecology. 60(4):711-718. http://dx.doi. org $/ 10.2307 / 1936608$

GOSLINE, W.A. 1971. Functional morphology and classification of teleostean fishes. University Press of Hawaii, Honolulu.

HAWKINS, D.K. \& QUINN, T.P. 1996. Critical swimming velocity and associated morphology of juvenile coastal cutthroat trout (Oncorhynchus clarki clarki), steelhead trout (Oncorhynchus mykiss), and their hybrids. Can. J. Fish Aquat. Sci. 53:1487-1496. http://dx.doi.org/10.1139/f96-085

LAGLER, K.F., BARDACH, J.E., MILLER, R.R. \& PASINO, D.R.M. 1977. Ichthyology. Wiley \& Sons, New York.

LANDWEBER, L. 1961. Motion of immersed and floating bodies. Handbook of Fluid Dynamics. McGraw-Hill.

LANGERHANS, R.B. \& REZNICK, D.N. 2010. Ecology and evolution of swimming performance in fishes: predicting evolution with biomechanics. p.200-248. In Fish locomotion: an eco-ethological perspective (O. Domenici \& B.G. Kapoor, eds.). Science Publisher, Enfield, New Hampshire, 534p. http://dx.doi.org/10.1201/b10190-8

LIGHTHILL, J. 1969. Hydrodynamics of aquatic animal propulsion-a survey. Annu. Rev. Fluid Mech. 1:413-446. http://dx.doi.org/10.1146/annurev. fl.01.010169.002213

MAKRAKIS, S., GOMES, L.C., MAKRAKIS, M.C., FERNANDEZ, D.R. \& PAVANELLI, C.S. 2007. The Canal da Piracema at Itaipu Dam as a fish pass system. Neotrop Ichthyol. 5(2):185-195. http://dx.doi.org/10.1590/ S1679-62252007000200013

MAKRAKIS, S., MIRANDA, L.E., GOMES, L.C., MAKRAKIS, M.C. \& FONTES JUNIOR, H.M. 2011. Ascent of Neotropical Migratory Fish in the Itaipu Reservoir Fish Pass. River Res Appl. 27:511-519. http:// dx.doi.org/10.1002/rra.1378

MONTEIRO, L.R. \& NEVES, F.M. 2003. Body shape and size divergence among populations of Poecilia vivipara in coastal lagoons of south-easten Brazil. J. Fish. Biol. 63(4):928-941. http://dx.doi.org/10.1046/j.10958649.2003.00199.x

MOTTA, P.J. \& WILGA, C.A.D. 1995. Anatomy of the feeding apparatus of the lemon shark, Negaprion brevirostris. J. Morphol. 226(33):309-329. http://dx.doi.org/10.1002/jmor.1052260307

NANAMI, A. 2007. Juvenile swimming performance of three fish species on an exposed sandy beach in Japan. J. Exp. Mar. Biol. Ecol. 348(11):1-10. http://dx.doi.org/10.1016/j.jembe.2007.02.016

OHLBERGER, J., STAAKS, G. \& HÖLKER, F. 2006. Swimming efficiency and the influence of morphology on swimming costs in fishes. J. Comp. Physiol. B. 176:17-25. PMid:16177894. http://dx.doi.org/10.1007/ s00360-005-0024-0

OJANGUREN, A.F. \& BRANA, F. 2003. Effects of size and morphology on swimming performance in juvenile brown trout (Salmo trutta L.). Ecol Fresh Fish. 12:241-246. http://dx.doi.org/10.1046/j.16000633.2003.00016.x 
PIORSKI, N.M., ALVES, J.R.L., MACHADO, M.R.B. \& CORREIA, M.M.F. 2005. Alimentação e ecomorfologia de duas espécies de piranhas (Characiformes: Characidae) do lago de Viana, estado do Maranhão, Brasil. Acta Amazôn. 35(1):63-70. http://dx.doi.org/10.1590/S004459672005000100010

RINCÓN, P.A., BASTIR, M. \& GROSSMAN, G.D. 2007. Form and performance: body shape and prey-capture success in four drift-feeding minnows. Oecologia. 152:345-355. PMid:17277930. http://dx.doi. org/10.1007/s00442-006-0651-5

SANTOS, H.A, POMPEU, P.S., VICENTINI, G.S., MARTINEZ, C.B. 2007 Swimming performance of the migratory Neotropical fish Leporinus reinhardti (Characiformes: Anostomidae). Neotrop Ichthyol. 5(2):139146. http://dx.doi.org/10.1590/S1679-62252007000200007

SANTOS, H.A., POMPEU, P.S., VICENTINI, G.S., MARTINEZ, C. B. 2008. Swimming performance of the freshwater neotropical fish: Pimelodus maculatus Lacepède, 1803. Brazil J. Biol. 68(2):433-439. PMid:18660976. http://dx.doi.org/10.1590/S1519-69842008000200029

SCARNECCHIA, D.L. 1988. The importance of streamlining in influencing fish community structure in channelized and unchannelized reaches of a prairie stream. Regul. Rivers: Res. Manage. 2(2):155-166. http://dx.doi. org/10.1002/rrr.3450020209

SUZUKI, H.I., VAZZOLER, A.E.A.M., MARQUES, E.E., PEREZ-LIZAMA, M.L.A. \& INADA, P. 2004. Reproductive ecology of fish assemblages. In The Upper Paraná River Floodplain: Physical Aspects, Ecology and Conservation (S.M. Thomaz, A.A. Agostinho \& N.S. Hahn, eds.) Backhuys Publishers, Leiden, p.271-292.
TEIXEIRA, I. \& BENNEMANN, S.T. 2007. Ecomorfologia refletindo a dieta dos peixes em um reservatório no sul do Brasil. Biota Neotrop. 7(2):67-77. http://dx.doi.org/10.1590/S1676-06032007000200007

VIDELER, J.J. 1993. Fish Swimming. Chapman and Hall, London, New York. PMid:7689822 PMCid:187998. http://dx.doi.org/10.1007/97894-011-1580-3

VIDELER, J.J. \& WARDLE, C.S. 1991. Fish swimming stride by stride: speed limits and endurance. Rev. Fish Biol. Fish. 1(1):23-40. http://dx.doi. org/10.1007/BF00042660

VON MISES, R. 1945. Theory of Flight. Dover Books, New York.

WAINWRIGHT, P.C., BELLWOOD, D.R. \& WESTNEAT, M.W. 2002. Ecomorphology of locomotion in labrid fishes. Envir. Biol. Fishes. 65:4762. http://dx.doi.org/10.1023/A:1019671131001

WARREN, M.L. \& PARDEW, M.G. 1998. Road crossings as barriers to small-stream fish movement. Trans. Am. Fish Soc. 127:637-644. http:// dx.doi.org/10.1577/1548-8659(1998) 127<0637:RCABTS>2.0.CO;2

WATSON, D.J. \& BALON, E.K. 1984. Ecomorphological analysis of fish taxocenes in rainforest streams of Northern Borneo. J. Fish Biol. 25:371384. http://dx.doi.org/10.1111/j.1095-8649.1984.tb04885.x

WEBB, P.W. 1975. Hydrodynamics and energetics of fish propulsion. Bull. Fish Res. Board. Can. 190:1-159.

WEBB, P.W. 1984. Body form, locomotion and foraging in aquatic vertebrates. Am. Zool. 24:107-120.

WEBB, P.W. \& WEIHS, D. 1986. Functional locomotor morphology of early life history stages of fishes. Trans. Am. Fish. Soc. 115:115-127. http:// dx.doi.org/10.1577/1548-8659(1986)115<115:FLMOEL >2.0.CO;2

WILKINSON, L. 1987. Systat: The System for Statistics. SYSTAT, Evanston. 